\title{
Marine debris on two Arctic beaches in the Russian Far East
}

\author{
Henrik Kylin ${ }^{1,2}$ \\ 'Department of Thematic Studies-Environmental Change, Linköping University, Linköping, Sweden; \\ ${ }^{2}$ Research Unit: Environmental Sciences and Management, North-West University, Potchefstroom, South Africa
}

\begin{abstract}
In August 2005, marine debris was counted on two Arctic beaches in the Russian Far East. On the north coast of the Chukchi Peninsula east of Kolyuchin Bay, a beach stretch of ca. $2.4 \mathrm{~km}$ held a total of 736 items, 0.024 items $\mathrm{m}^{-2}$, while no more than 0.0011 items $\mathrm{m}^{-2}, 12$ items in total, were found on a beach stretch of ca. $1.2 \mathrm{~km}$ on southern Wrangel Island. The likely explanation for this difference is that the area around the mainland beach is ice-free for a longer period each year, but a contributing factor may be that late spring ice movement removed plastic from the beach on Wrangel Island. The language on the few items with identifiable labels was for the most part Russian or English, making the Chukchi Sea a possible source region. Beaches at the same latitude in the Atlantic may hold more debris on account of the higher human population density, more shipping and transport of floating debris unhindered by a narrow strait that is ice-covered much of the year. Fishing gear blown across the tundra is suggested as a potential threat to reindeer and other terrestrial wildlife.
\end{abstract}

To access the supplementary material, please visit the article landing page

\section{Introduction}

Interest in the occurrence and possible negative effects of plastics in the marine environment dates back at least to the early 1970s (Carpenter et al. 1972; Carpenter \& Smith 1972). Although some studies on various aspects of contamination with debris and microplastics did appear in the intervening years (e.g., Eriksson $\delta$ Burton 2003 and references therein), it was not until the 21 st century that interest in the problems caused by marine debris and microplastics was realized more widely (Vegter et al. 2014; Seltenrich 2015). Plastic debris causes socio-economic impacts and affects marine animals. Plastic entangles large and small animals, is ingested by them, facilitates dispersion of non-native species and contains toxic compounds that find their way into organisms. Floating and sunken debris affects fishing and tourism, blocks water intakes and-especially discarded, floating nets-causes navigational hazards (Thompson et al. 2011). Because of their long half-life, plastics and other debris in the environment are expected to constitute an environmental problem for hundreds of years.

The past decade has seen a rapid increase in the number of publications covering marine debris on beaches and the seafloor in various parts of the world (e.g.,

\section{Keywords}

Plastic debris; Chukchi Sea; Chukchi Peninsula; Kolyuchin Bay; Wrangel Island; pollution

\section{Correspondence}

Henrik Kylin, Department of Thematic Studies-Environmental Change, Linköping University, SE-181 83 Linköping, Sweden. E-mail: henrik.kylin@liu.se
Eriksson et al. 2013; Rosevelt et al. 2013; Bouwman et al. 2016; Poeta et al. 2016; Bergmann et al. 2017; Cózar et al. 2017; Tekman et al. 2017). At low latitudes (Bouwman et al. 2016; Lavers $\delta$ Bond 2017) and in the Subantarctic (Eriksson et al. 2013), remote beaches, that is, beaches with no or little local human habitation, may collect high numbers of debris items. However, the situation in the Arctic is still poorly known (Trevail et al. 2015; Bergmann et al. 2017; Halband \& Herzke 2017). However, recent evidence suggests significant plastic pollution on northern shores of the Svalbard Archipelago (Bergmann et al. 2017), debris and microplastic floating at the sea surface (Bergmann et al. 2015; Lusher et al. 2015; Cózar et al. 2017). Debris was also recorded from the Barents Sea (Grøsvik et al. 2018) and increasing quantities on the deep seafloor of Fram Strait (Tekman et al. 2017).

Interpreting the amount of debris on a beach is complex. Increased awareness of the problems caused by marine debris has led to the United Nations Environmental Programme (Cheshire et al. 2009), the European Union (Galgani et al. 2013) and the Oslo/Paris Convention (OSPAR 2010) developing guidelines for studying these environmental issues. Sampling frequency, seasonal differences and longevity of the monitoring program will affect the results substantially (Eriksson et al. 2013; 
Ryan et al. 2014; Poeta et al. 2016; Lavers \& Bond 2017). However, for remote locations that are not visited regularly, occasional opportunistic counts may have to suffice for a first assessment.

Although debris on low Arctic beaches has been discussed (Trevail et al. 2015; Halband \& Herzke 2017), the situation in the less populated areas of the Arctic seems to have received attention mostly in Svalbard (Bergmann et al. 2015; Bergmann et al. 2017; Hallanger \& Gabrielsen 2018). With the expected increase in shipping in the Arctic in the wake of climate change (Yangjun et al. 2018), it becomes imperative to extend such investigations to those areas where shipping has been restricted by heavy ice. To help fill in this information gap, I here report the results of a count of debris on two Arctic beaches in the Russian Far East, which may serve as baseline information for future, more systematic studies in the area.

\section{Materials and methods}

The observations took place during the Beringia 2005 expedition. The main task of the expedition was to study terrestrial and limnic ecology of Beringia, the area adjacent to the Bering Sea, roughly delineated in the west by the Lena River, Russia, and in the east by the Mackenzie River, Canada (Rickberg 2006). The Swedish research icebreaker Oden was the logistic base, transporting researchers between stations and allowing some marine research during passage.

At two of the planned stations in Chukotka Autonomous Okrug, opportunity arose to count marine debris on the beaches. Site 1 (Fig. 1), visited 7 August 2005, was located on mainland Chukotka east of Kolyuchin Bay $\left(\mathrm{N} 67^{\circ} 04.4^{\prime}, \mathrm{W} 173^{\circ} 21.7^{\prime}\right)$, where $2.4 \mathrm{~km}$ of beach, with an area of ca. $31000 \mathrm{~m}^{2}$, was surveyed. On this beach several remains of bowhead (Balaena mysticetus) and gray whales (Eschrichtius robustus; Fig. 2a, b) and walruses (Odobenus rosmarus) were found in various stages of decay and weathering. Site 2, visited 14 August 2005, was on the south coast of Wrangel Island $\left(\mathrm{N} 70^{\circ} 53.6^{\prime}, \mathrm{W} 179^{\circ} 25.4^{\prime}\right)$, where the survey covered a beach stretch of $1.2 \mathrm{~km}$, ca. $11000 \mathrm{~m}^{2}$. Both were sandy beaches, site 1 with a prominent (3-7 $\mathrm{m}$ high) coastal dune 10-30 $\mathrm{m}$ from the water (Fig 2c, d); site 2 with a low and indistinct $(<1 \mathrm{~m})$ dune 5-15 $\mathrm{m}$ from the water with evidence-turf scraped off and deposited inland-that moving ice had recently been pushed at least as far as up as the dune. Furthermore, no animal remains were found on the Wrangel Island beach. The total area survey was estimated based on measuring the distance between the water and the dune every $100 \mathrm{~m}$ and calculating the mean distance between water and dune.

All visible debris between the water and the respective dune was counted. In practice, the smallest visible pieces were about $2 \mathrm{~cm}$. There was no practical possibility to collect or weigh the debris.

At Kolyuchin, local hunters acting as guards against polar bear were asked for additional information on observed consequences of marine debris.

\section{Results and discussion}

There seems to be few previous investigations of debris on the shores of the Chukchi and Beaufort seas. The only report

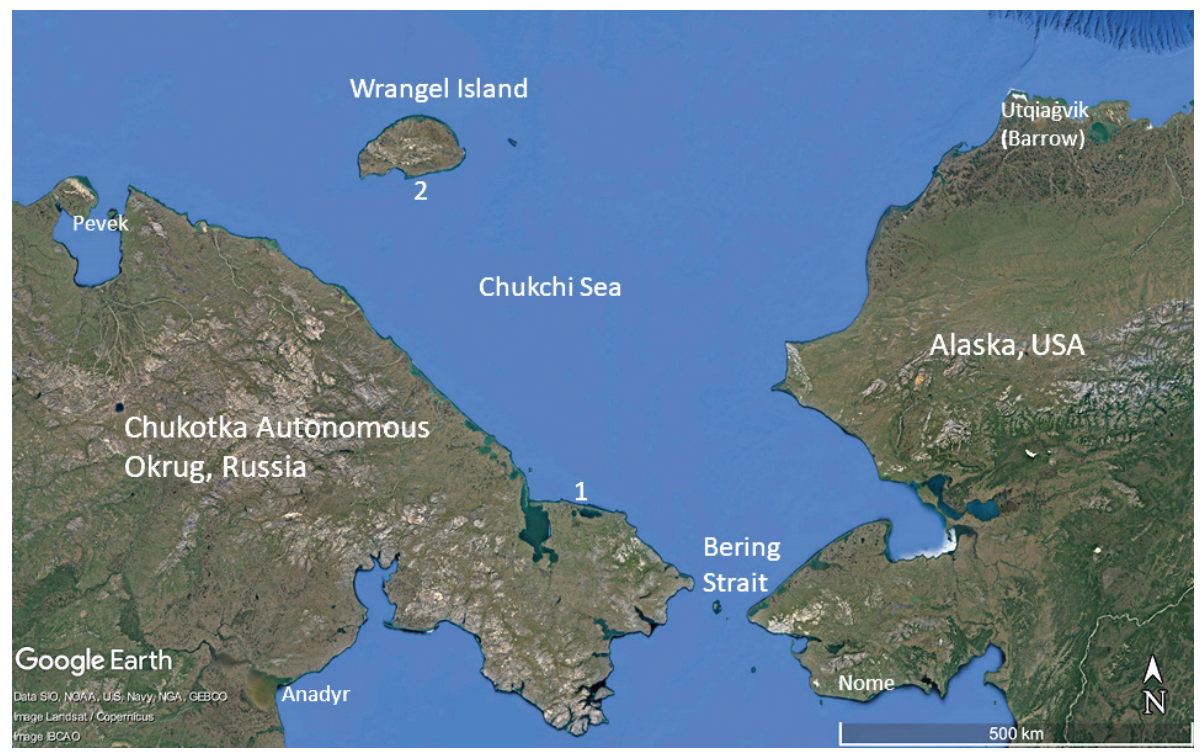

Fig. 1 Map of the Chukchi Sea area showing locations of the sampled beaches at (1) Koluychin Bay and on (2) Wrangel Island. 

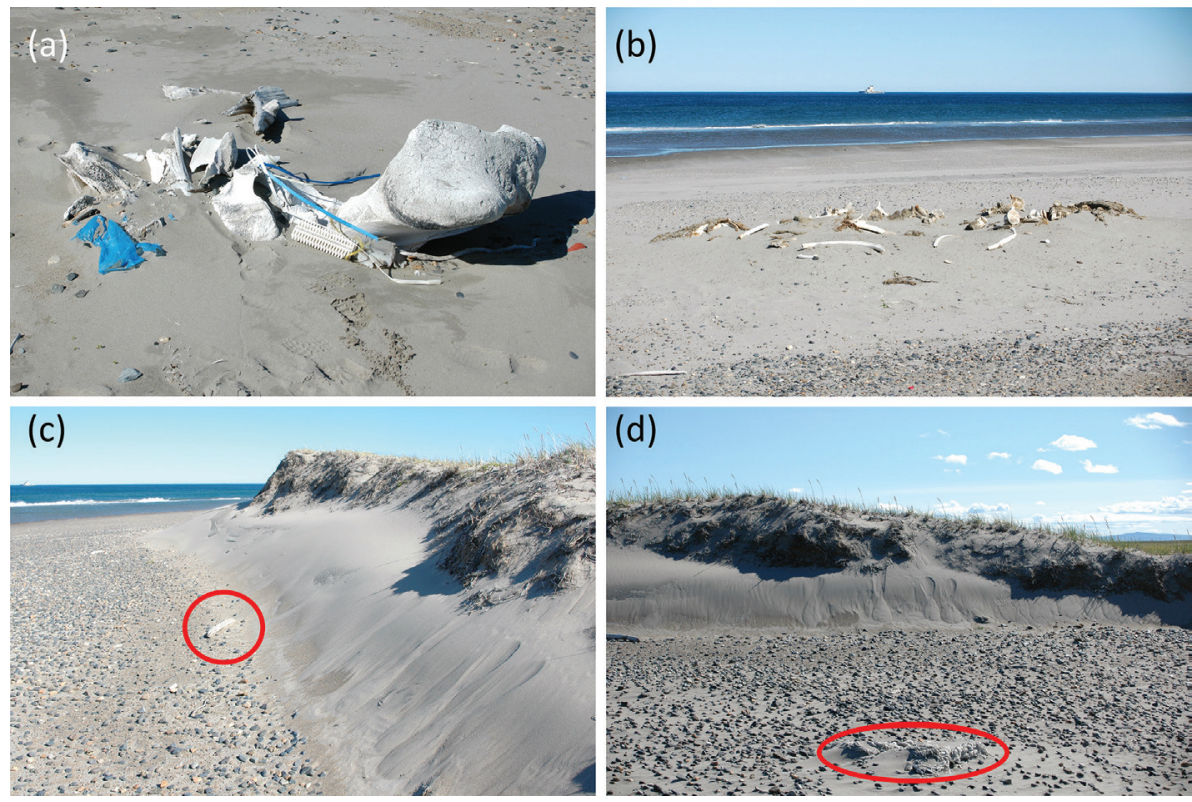

Fig. 2 Photographs from site 1 on the north-eastern coast of mainland Chukotka Autonomous Okrug, east of Kolyuchin Bay (N6704.4', W173²1.7'). (a) An old, weathered whale jawbone with entangled plastics. According to the local hunters, whale and other animal skeletons may remain on the beach for decades and often trap marine debris. (b) Skeletal remains of a recently dead juvenile grey whale (Eschrichtius robustus), dispersed likely by polar bears (Ursus maritimus). Several pieces of rope and cargo strapping were entangled in these remains. (c) The coastal dune in relation to the sea. Encircled in the centre are parts of a mammoth (Mammutus primigenius) tusk. (d) The coastal dune. Encircled in the foreground is a fishing net partially buried in the sand. (Photos by Henrik Kylin, 7 August 2005.)

I have been able to find is that of Wong et al. (1976), reporting a study of the shores of the Canadian sector of the Beaufort Sea. That investigation was primarily undertaken to study shore contamination by clumps of oil and tar; plastic debris were counted as a by-product and the data presented in a way that is not useful today. There is an interesting comment that various debris that had been blown inland accumulated at the same place as driftwood blown inland by storms. The same observation was done at Kolyuchin (site 1) in this study, but inland debris was not counted by me.

At site 1, on the north coast of the Chukchi Peninsula, the surveyed beach held 0.024 items $\mathrm{m}^{-2}$, while no more than 0.0011 items $\mathrm{m}^{-2}$ were found on the surveyed beach stretch at site 2 on southern Wrangel Island (Table 1; Supplementary Table S1). The most obvious explanation for this difference is that the mainland beach is ice-free for a longer time each year than the island beach and closer to fishing activities in the Chukchi Sea. The likelihood of ice action directly on the beach also seems different. At Koluychin (site 1, mainland), there were several remains, fresh as well as weathered, of whales and walruses as well as subfossil remains of other mammals on the seaward side of the coastal dune (Fig. 2a-c). Pieces of fishing gear, ropes and similar items were often entangled
Table 1 Debris on beaches at Koluychin Bay and Wrangel Island in August 2005. More detailed data and international debris codes are given in Supplementary Table S1.

\begin{tabular}{lcc}
\hline Sampling information/ & Koluychin Bay & Wrangel Island \\
types of debris & & \\
\hline Date & $07-08-2005$ & $14-08-2005$ \\
Longitude & $67^{\circ} 04.4^{\prime} \mathrm{N}$ & $70^{\circ} 53.6^{\prime} \mathrm{N}$ \\
Latitude & $173^{\circ} 21.7^{\prime} \mathrm{W}$ & $179^{\circ} 25.4^{\prime} \mathrm{W}$ \\
Distance to water (m) & $0-20$ & $0-15$ \\
Survey length (km) & 2.4 & 1.2 \\
Approximate survey area (m²) & 31000 & 11000 \\
Plastics/rubber (total items) & 656 & 12 \\
Plastics fisheries (total items) & 41 & 0.0011 \\
Plastic/rubber (items $\mathrm{m}^{-2}$ ) & 0.021 & \\
Plastics fisheries (items $\mathrm{m}^{-2}$ ) & 0.0012 & \\
Cloth (items $\mathrm{m}^{-2}$ ) & 0.000064 & \\
Metal (items $\mathrm{m}^{-2}$ ) & 0.00027 & \\
Glass/ceramics (items $\mathrm{m}^{-2}$ ) & 0.0017 &
\end{tabular}

in such skeletal remains, the remains seemingly preventing the debris to blow further inland. In contrast, there were no skeletal remains on the Wrangel Island beach. Instead, there were obvious signs that the ice had moved 
across the beach and scraped off vegetation from the low coastal dune. Such ice action would also remove any skeletal remains and much debris. Ice action may contribute to the disintegration of plastic into smaller pieces or to the burial of debris in the sand or transport back to the sea. The observation that debris on the bottom of the Arctic Ocean is increasing may be partly due to increased ice action at beaches, at least in the North Atlantic (Tekman et al. 2017).

The area around the Chukchi Sea has a sparse human population (Rickberg 2006). The largest town along the northern coast of the Chukotka is Pevek, with ca. 6000 inhabitants, some $700 \mathrm{~km}$ west of site 1 . The town of Bilbino, with an additional 7000 people, is located about $200 \mathrm{~km}$ inland, south-west of Pevek. Because of the long periods of ice cover yearly, and the absence of large ports along the coast, commercial shipping is limited. Apart from Pevek and Bilibino, the human population along the rest of the northern Chukotka coast is limited to a few settlements with a few hundred inhabitants. The largest settlement, Neshkán, located about $20 \mathrm{~km}$ east of site 1 , has about 700 residents, while the population of other settlements are reported to be in the low hundreds (Rickberg 2006). There is no habitation on Wrangel Island, but the national park office is permanently manned and the island is visited by cruise ships during summer (Rickberg 2006). Furthermore, although Wrangel Island (site 2) is closer to Pevek than Koluychin (site 1), shipping lanes are likely closer Kolyuchin than Wrangel Island.

With the low number of inhabitants and limited shipping in the adjacent waters, it is not surprising that debris, generally, was scarce. In comparison, debris densities seem to be higher on beaches in in northernmost Norway and Svalbard at similar or even higher latitudes than in the beaches studied here (Trevaile et al. 2015; Bergmann et al. 2017; Hallanger \& Gabrielsen 2018). One obvious explanation is that the human population is higher and shipping more intense in the North Atlantic area than in the Chukchi Sea. However, human population densities cannot be the only explanation for the relative paucity of debris on the Chukotka beaches compared to the north Atlantic. High densities of debris have been reported from beaches on islands with virtually no human population in the Indian, Pacific and Southern oceans (Eriksson et al. 2013; Bouwman et al. 2016; Lavers \& Bond 2017). Common to northern Norway and the oceanic islands in the south is an exposure to oceanic currents carrying debris from densely populated source areas. Indeed, the Arctic Ocean has been described as a dead end for floating marine debris from the North Atlantic (Cózar et al. 2017). Hence, exposure to ocean currents is likely an important factor for the density of debris on remote beaches.
In other situations, for example, on beaches of more populated areas, local emission of debris is likely the governing factor (Rosevelt et al. 2013; Poeta et al. 2016).

The origin of the debris observed in this study was difficult to ascertain as most labels had been abraded. Of the labels that could be read on spray cans, five had Russian text while three were in English. Of the drinking bottles, 23 labels were in English, 10 in Russian and 14 unreadable. The origins of these items may very well be from the area around the Chukchi and Beaufort seas. It is also possible that debris transported via rivers emptying in the Arctic Ocean may reach the two beaches. Four shotgun cases were found, all of which had Cyrillic script, while the hardhat had Chinese script and the rucksack was of a Swedish brand that is sold worldwide. Remnants of fishing gear and other floating material had little growth of goose barnacles or bryozoans, indicating that they had been lost in the nearby seas rather than having spent much time floating around. Another argument for a regional origin, that is, Chukchi and Beaufort seas, of the debris is that heavy ice during much of the year limits shipping in the area (Yangjun et al. 2018). The only other pathway for seaborne debris to reach these two shores is via the narrow Bering Strait, which also is ice-covered during much of the year (Yangjun et al. 2018).

Local Chukchi hunters spontaneously related how they would find dead reindeer entangled in fishing nets blown in from the sea many kilometers inland several times each year. I did not determine the exact meaning of "several times each year" or "many kilometres." Problems with marine fauna caught by rouge fishing gear are well known (Vegter et al. 2014), but the entanglement of terrestrial animals in fishing gear is less well characterized. Bergmann et al. (2017) and Hallanger \& Gabrielsen (2018) report that birds and reindeer have been observed trapped or dead in stranded fishing nets in Svalbard, but, as yet, there seems to be no actual quantification of the problem reported in the scientific literature. Entanglement of terrestrial biota in fishing gear is likely a larger problem on the Arctic tundra than elsewhere. Frequent strong winds and the lack of high vegetation allow stranded fishing gear to be carried further inland on the tundra than in most other biomes. The scale of this problem needs further investigation, but it should be noted that if shipping through the North-east Passage increases as a consequence of climate change, there will also be an increase of marine debris along the whole Siberian coast.

\section{Disclosure statement}

The author reports no conflict of interest. 


\section{Acknowledgements}

Without the help and assistance of the Swedish Polar Research Secretariat and the officers and crew of the icebreaker Oden, this work could not have been possible. The author is indebted to Cecilia Eriksson for suggesting that this work should be performed although it was not originally included in the expedition plan.

\section{References}

Bergmann M., Lutz B., Tekman M.B. \& Gutow L. 2017. Citizen scientists reveal: marine litter pollutes Arctic beaches and affects wild life. Marine Pollution Bulletin 125, 535-540, doi: 10.1016/j.marpolbul.2017.09.055.

Bergmann M., Sandhop N., Schewe I. \& D'Hert D. 2015. Observations of floating anthropogenic litter in the Barents Sea and Fram Strait, Arctic. Polar Biology 39, 553-560, doi: 10.1007/s00300-015-1795-8.

Bouwman H., Evans S.W., Cole N., Choong Kwet Yive N.S. \& Kylin H. 2016. The flip-or-flop boutique: marine debris on the shores of St Brandon's Rock, an isolated atoll in the Indian Ocean. Marine Environmental Research 114, 58-64, doi: 10.1016/j.marenvres.2015.12.013.

Carpenter E.J., Andersen S.J., Harvey G.R., Miklas H.P. \& Peck B.B. 1972. Polystyrene spherules in coastal waters. Science 178, 749-750, doi: 10.1126/science.178.4062.749.

Carpenter E.J. \& Smith K.L. 1972. Plastics on the Sargasso Sea surface. Science 175, 1240-1241, doi: 10.1126/ science.175.4027.1240.

Cheshire A.C., Adler E., Barbière J., Cohen Y., Evans S., Jarayabhand S., Jeftic L., Jung R.T., Kinsey S., Kusui E.T., Lavine I., Manyara P., Oosterbaan L., Pereira M.A., Sheavly S., Tkalin A., Varadarajan S., Wenneker B. \& Westphalen G. 2009. UNEP/IOC guidelines on survey and monitoring of marine litter. UNEP Regional Seas Reports and Studies 186. IOC Technical Series 83. Nairobi: United Nations Environment Programme, Intergovernmental Oceanographic Commission.

Cózar A., Martí E., Duarte C.M., García-de-Lomas J., van Sebille E., Ballatore T.J., Eguíluz V.M., González-Gordillo J.I., Pedrotte M.L., Echevarría F., Troublè R. \& Irigoien X. 2017. The Arctic Ocean as a dead end for floating plastics in the North Atlantic branch of the thermohaline circulation. Science Advances 3, el600582, doi: 10.1126/ sciadv. 1600582 .

Eriksson C. \& Burton H. 2003. Origin and biological accumulation of small plastic particles in fur seals from Macquarie Island. Ambio 32, 380-384, doi: 10.1639/0044-7447(2003)032[0380:OABAOS]2.0.CO;2.

Eriksson C., Burton H., Fitch S., Schulz M. \& van den Hoff J. 2013. Daily accumulation rates of marine debris on sub-Antarctic island beaches. Marine Pollution Bulletin 66, 199-208, doi: 10.1016/j.marpolbul.2012.08.026.

Galgani F., Hanke G., Werner S., Oosterbaan L., Nilsson P., Fleet D., McKinsey S., Thompson R., Van Franeker J., Vlachogianni T., Scoullos M., Mira Veiga J., Palatinus A.,
Matiddi M., Maes T., Korpinen S., Budziak A., Leslie H., Gago J. \& Liebezeit G. 2013. MSFD technical group on marine litter, guidance on monitoring of marine litter in European seas. JRC Scientific and Policy Reports. Luxembourg: Publications Office of the European Union. doi: 10.2788/99475.

Grøsvik B.E., Prokhorova T., Eriksen E., Krivosheya P., Horneland P.A. \& Prozorkevich D. 2018. Assessment of marine litter in the Barents Sea, a part of the Joint NorwegianRussian Ecosystem Survey. Frontiers in Marine Science 5, UNSP 72, doi: 10.3389/fmars.2018.00072.

Halband C. \& Herzke D. 2017. Marine plastics and microplastics. In: AMAP assessment 2016: chemicals of emerging Arctic concern. Pp. 269-275. Oslo: Arctic Monitoring and Assessment Programme.

Hallanger I.G. \& Gabrielsen G.W. 2018. Plastic in the European Arctic. Norwegian Polar Institute Brief Report 45. Tromsø: Norwegian Polar Institute.

Lavers J.L. \& Bond A.L. 2017. Exceptional and rapid accumulation of anthropogenic debris on one of the world's most remote and pristine islands. Proceedings of the National Academy of Sciences of the United States of America 114, 60526055, doi: 10.1073/pnas.1619818114.

Lusher A.L., Tirelli V., O'Connor I. \& Officer R. 2015. Microplastics in Arctic polar waters: the first reported values of particles in surface and sub-surface samples. Scientific Reports 5, article no. 14947, doi: 10.1038/srep 14947.

OSPAR. 2010. Guideline for monitoring marine litter on the beaches in the OSPAR maritime area. London: OSPAR Commission.

Poeta G., Battisti C., Bazzichetto M. \& Acosta A.T.R. 2016. The cotton buds beach: marine litter assessment along the Tyrrhenian coast of central Italy following the marine strategy framework directive criteria. Marine Pollution Bulletin 113, 266-270, doi: 10.1016/j.marpolbul.2016.09.035.

Rickberg S. (ed.) 2006. Yearbook 2005. Stockholm: Swedish Polar Research Secretariat.

Rosevelt C., Los Huertos M., Garza C. \& Nevins H.M. 2013. Marine debris in central California: quantifying type and abundance of beach litter in Monterey Bay, CA. Marine Pollution Bulletin 71, 299-306, doi: 10.1016/j. marpolbul.2013.01.015.

Ryan P.G., Lamprecht A., Swanelpoel D. \& Moloney C.L. 2014. The effect of fine-scale sampling frequency on estimates of beach litter accumulation. Marine Pollution Bulletin 88, 249-254, doi: 10.1016/j.marpolbul.2014.08.036.

Seltenrich N. 2015. New link in the food chain? Marine plastic pollution and seafood safety. Environmental Health Perspectives 123, A34-A41, doi: 10.1289/ehp.123-A34.

Tekman M.B., Krumpen T. \& Bergmann M. 2017. Marine litter on deep Arctic seafloor continues to increase and spreads to the North at the HAUSGARTEN observatory. Deep-Sea Research Part I 120, 88-99, doi: 10.1016/j. dsr.2016.12.011.

Thompson R.C., La Belle B.E., Bouwman H. \& Neretin L. 2011. Marine debris as a global environmental problem: introducing a solutions-based framework focused on plastic. A STAP Information Document. Washington, DC: Global Environment Facility. 
Trevail A.M., Kuhn S. \& Gabrielsen G.W. 2015. The state of marine microplastic pollution in the Arctic. Norwegian Polar Institute Brief Report 33. Tromsø: Norwegian Polar Institute.

Vegter A.C., Barletta M., Beck C., Borrero J., Burton H., Compbell M.L., Costa M.F., Eriksen M., Eriksson C., Estrades A., Gilardi K.V.K., Hardesty B.D., Ivar do Sul J.A., Lavers J.L., Lazar B., Lebreton L., Nichols W.J., Ribic C.A., Ryan P.G., Schuyler Q.A., Smith S.D.A., Takada H., Townsend K.A., Wabnitz C.C.C., Wilcox C., Young L.C. \& Hamann M. 2014. Global research priorities to mitigate plastic pollution impacts on marine wildlife. Endangered Species Research 25, 225-247, doi: 10.3354/esr00623.

Wong C.S., MacDonald D. \& Cretney W.J. 1976. Tar and particulate pollutants on the Beaufort Sea coast. Beaufort Sea Project Technical Report 13. Victoria, BC: Ocean and Aquatic Sciences Canada.

Yangjun W., Ren Z., Shanshan G. \& Longxia Q. 2018. Investigating the effect of Arctic sea routes on the global maritime container transport system via a generalized Nash equilibrium model. Polar Research 37, article no. 157042, doi: $10.1080 / 17518369.2018 .1547042$. 